\title{
Studi Awal Karakteristik Tegangan Ouput Generator Magnet Permanen dan Generator DC pada Turbin Kubah Masjid Putar
}

\author{
Wiwin A.Oktaviani ${ }^{1}$, Taufik Barlian ${ }^{2}$, Yosi Apriani ${ }^{3}$ \\ Jurusan Teknik Elektro, Fakultas Teknik, Universitas Muhammadiyah Palembang \\ Jalan Jend. A. Yani 13 Ulu Seberang Ulu II Palembang, 30262 \\ ${ }^{1}$ wiwin_oktaviani@um-palembang.ac.id \\ 2tfk_ap@yahoo.co.id \\ 3yosi_aprianidum-palembang.ac.id
}

Intisari - Setiap yang berputar memiliki potensi energi kinetik, tidak terkecuali putaran kubah masjid. Penelitian ini bertujuan untuk mengetahui potensi pemanfaatan kubah putar masjid sebagai penghasil energi listrik skala kecil. Generator yang diuji cobakan adalah generator magnet permanen dan generator DC yang dirangkaikan dengan turbin kubah putar. Pengujian dilakukan di dua lokasi, di Jembatan Musi 2 Palembang dan di perairan Sungsang Kabupaten Banyuasin untuk mengukur besaran tegangan dan arus output yang dihasilkan pada berbagai kecepatan angin menggunakan multimeter dan anemometer. Hasil penelitian menunjukkan bahwa tegangan yang dihasilkan oleh putaran kubah masjid menggunakan generator magnet permanen mampu mencapai 14,21 V pada kecepatan angin 3,8 m/det dibandingkan dengan generator DC yang hanya mencapai $3 \mathrm{~V}$ pada kecepatan angin $8 \mathrm{~m} /$ det. Jika ditinjau dari besaran arus, generator magnet permanen menghasilkan arus konstan sebesar 0,3 A sedangkan pada generator DC arus yang dihasilkan tidak terukur karena nilainya yang amat kecil. Penelitian ini menunjukkan bahwa kubah putar masjid dapat dijadikan sebagai turbin angin pada daerah yang memiliki kecepatan angin rendah.

Kata kunci — kubah masjid putar,generator magnet permanen,generatorDC, turbin angin kecepatan rendah

Abstract - Every spinning has kinetic energy potential; the mosque dome is no exception. This study aims to determine the potential use of the mosque's turning dome as a producer of small-scale electrical energy. Two types of the generator were tested, which were permanent magnet generator and DC generator, which were coupled with a rotary dome turbine. The test was carried out at two locations, at Palembang Musi 2 Bridge and in the waters of Sungsang, Banyuasin Regency, to measure the amount of voltage and output current generated at various wind speeds using a multimeter and anemometer. The results showed that the voltage generated by the mosque's dome rotation using a permanent magnet generator was able to reach $14.21 \mathrm{~V}$ at wind speeds of 3.8 $\mathrm{m} / \mathrm{sec}$ compared to DC generators, which only reached $3 \mathrm{~V}$ at $8 \mathrm{~m} / \mathrm{s}$ wind speed. When viewed from the amount of current, permanent magnet generators produce a constant current of $0.3 \mathrm{~A}$ while in DC generators, the current generated is not measurable because the value is minimal. This research shows that the mosque's rotary dome can be used as a wind turbine in areas that have low wind speeds.

Keywords - rotary mosque domes, permanent magnet generators, generator DC, low speed wind turbines 


\section{PENDAHULUAN}

Masjid tidak saja merupakan tempat ibadah, namun berfungsi juga sebagai pusat pemberdayaan ekonomi, sosial kemasyarakatan, pendidikan dan seni budaya. Dengan demikian dalam tatanan masyarakat muslim, masjid menjadi basis pemberdayaan masyarakat [1]. Keberadaan dan aktivitas suatu masjid di orientasikan untuk menjadi agen of change terhadap masyarakat menuju masyarakat madani (civil society) yang berlandaskan pada tuntunan Al-Qur'an dan AlHadist [2].Sebagaimana bangunan ibadah lainnya, masjid memiliki bentuk yang khas. Elemen bangunan yang umum dimiliki oleh masjid adalah: menara, kubah, elemen lengkung setengah lingkaran, setengah ellips, lengkung lancip dsb., mihrab (tempat imam), dan gerbang dengan jumlah tunggal maupun lebih dari satu [3]. Kubah merupakan elemen masjid yang paling mudah untuk dikenali. Bentuknya yang menyerupai setengah bola dengan dekorasi warna yang mencolok disertai elemen hiasan menjadikan kubah sebagai pusat bangunan masjid. Saat ini, cukup banyak tersedia kubah yang terbuat dari bahan seng yang disusun berbilah-bilah sehingga berputar ketika ditiup angin, menjadikan kubah lebih menarik tampilannya.Kubah yang dapat berputar ini mengandung energi kinetik yang dapat dimanfaatkan sebagai turbin angin penghasil energi listrik alternatif, terutama bagi masjid-masjid di daerah yang belum terjangkau listrik. Penelitian [4] menunjukkan bahwa pembangkit hybrid kubah putar dan solar cell mampu menghasilkan daya pengisian batere sebesar 287,28 Watt selama 9 jam dan mampu menyalakan lampu berdaya 45 Watt selama 2 jam.

Bentuk kubah putar menyerupai turbin ventilator yang biasa terdapat pada gedung gedung besar tempat penyimpanan sebagai alat penghisap udara keluar. Turbin ventilator bila digunakan sebagai turbin angin mampu menghasilkan daya yang berkisar antara 5,75 Watt hingga 10,9 Watt ([5], [6], [7], [8] ) dengan kecepatan angin minimum yang menghasilkan daya sebesar $3 \mathrm{~m} / \mathrm{s}$. Dari penelitian-penelitian ini dan karena kemiripan bentuknya, dapat diperkirakan bahwa kubah putar masjid sebagai sistem mandiri memiliki potensi untuk dimanfaatkan sebagai turbin angin penghasil energi listrik skala kecil terutama pada daerah dengan kecepatan angin yang rendah.Selain turbin angin, komponen penting lainnya untuk menghasilkan listrik adalah generator. Jenis generator yang umum digunakan bersama turbin angin di daerah yang memiliki kecepatan angin rendah adalah generator DC dan generator magnet permanen. Pada kecepatan angin rata-rata 2,22 $\mathrm{m} / \mathrm{det}$ generator DC mampu menghasilkan daya ratarata 136,3 Watt dengan tegangan rata-rata sebesar 2,56 Volt [9]. Sedangkan pada kecepatan angin rata-rata $9.0 \mathrm{~m} / \mathrm{s}$ mampu menghasilkan tegangan sebesar 10.5 volt dengan arus pengisian baterai tanpa beban sebesar 0,30 A dan arus pengisian baterai dengan beban sebesar 0,38 A [10]. Kedua penelitian.menggunakan jenis turbin angin berupa baling-baling kipas berbentuk vertikal. Jika pada generator DC medan magnet dihasilkan oleh kumparan maka pada generator magnet permanen, medan magnet dihasilkan oleh magnet itu sendiri. Jenis magnet yang umum dipakai adalah magnet jenis rare earth magnet. Salah satunya adalah magnet neodymium. Magnet ini merupakan magnet permanen terkuat karena mampu menghasilkan medan magnet yang lebih kuat dibandingkan ferit atau alnicomagnet [11] sehingga cocok diterapkan pada generator berputaran rendah dan tanpa energi listrik awal [12] untuk membentuk medan magnetnya. Generator magnet permanen tipe fluks aksial relatif lebih tepat digunakan dengan turbin angin berkecepatan rendah [13]. Jarak antara stator dan rotor pada generator aksial turut mempengaruhi besarnya tegangan $\mathrm{AC}$ yang dihasilkan dimana semakin kecil jaraknya akan menghasilkan tegangan yang lebih besar baik pada kondisi berbeban maupun tak berbeban [14].

Pada artikel ini, akan dibahas potensi pemanfaatan kubah putar masjid sebagai suatu pembangkit listrik mandiri, baik digunakan dengan generator magnet permanen maupun generator DC. Pengujian dilakukan di dua tempat; Jembatan Musi 2 Palembang untuk pengujian generator magnet permanen dan; perairan lepas Sungsang Kabupaten Banyuasin Sumatera Selatan untuk generator DC. Pertimbangan pemilihan tempat pengujian didasarkan pada dimensi masing-masing 
generator, dimana diasumsikan untuk memutar generator DC membutuhkan kecepatan angin yang relatif lebih tinggi dibandingkan generator magnet permanen. Penelitian ini merupakan kelanjutan dari penelitian sebelumnya [15].

\section{TINJAUAN PUSTAKA}

\section{A. Energi Angin}

Konversi energi kinetik angin menjadi energi listrik dilakukan dengan memanfaatkan angin untuk menggerakkan bilah-bilah pada kubah putar yang terkopel dengan generator. Energi kinetik angin pada kubah putar mengikuti persamaaan berikut :

$$
E_{k}=\frac{1}{2} m v^{2}
$$

dengan :

$\mathrm{m}=\operatorname{massa}(\mathrm{kg})$

$\mathrm{V}=$ kecepatan angin $(\mathrm{m} /$ detik$)$

Dalam persamaan aliran, energi kinetik dinyatakan sebagai:

$$
P=\frac{1}{2} \rho A v^{3}
$$

dengan :

$\mathrm{P}=$ tenaga dalam watts

$\rho=$ density udara $\left(1.225 \mathrm{~kg} / \mathrm{m}^{3}\right.$ di permukaan laut)

$\mathrm{A}=$ permukaan kincir $\left(\mathrm{m}^{2}\right)$

$\mathrm{V}=$ kecepatan angin dalam meters/detik

Tenaga dari aliran udara bebas sebagiannya tidak dapat dikonversi dikarenakan ada aliran udara yang tidak "ditangkap" oleh bilah kubah

[15]. Menurut Hukum Betz, “ banyaknya energi kinetik angin yang dapat menjadi energi yang menggerakkan rotor maksimal hanya 59,3\%" yang dikenal sebagai Betz Limit, sehingga daya yang dihasilkan turbin angin adalah:

$$
P=0.5 \rho A C_{p} V^{3} N_{g} N_{b}
$$

dengan :

$\mathrm{C}_{\mathrm{p}}=0,59$ Betz limit

$\mathrm{N}_{\mathrm{g}}=$ efisiensi generator

$\mathrm{N}_{\mathrm{b}}=$ efisiensi gearbox/bearing
Badan Metereologi, Klimatologi dan Geofisika (BMKG) membagi kelas-kelas angin berdasarkan kecepatanya, seperti ditunjukkan pada Tabel 1 berikut :

Tabel 1. Klasifikasi angin berdasarkan kecepatan

\begin{tabular}{cccc}
\hline $\begin{array}{c}\text { Kelas } \\
\text { angin }\end{array}$ & \multicolumn{3}{c}{ Kecepatan Angin dalam } \\
\hline 1 & $0,3-1,5$ & $\mathbf{k m} / \mathbf{j a m}$ & $\mathbf{k n o t} / \mathbf{j a m}$ \\
\hline 2 & $1,5-3,3$ & $5,5-11,9$ & $0,58-2,92$ \\
$\mathbf{3}$ & $\mathbf{3 , 4}-\mathbf{5 , 4}$ & $\mathbf{1 2 , 0}-\mathbf{1 9 , 5}$ & $\mathbf{6 , 6 1}-\mathbf{1 0 , 5}$ \\
4 & $5,5-7,9$ & $19,6-28,5$ & $10,7-15,4$ \\
5 & $8,0-10,7$ & $28,6-38,5$ & $15,6-20,8$ \\
6 & $10,8-13,8$ & $38,6-49,7$ & $21,0-26,8$ \\
7 & $13,9-17,1$ & $49,8-61,5$ & $27,0-33,3$ \\
$\mathbf{8}$ & $\mathbf{1 7 , 2}-\mathbf{2 0 , 7}$ & $\mathbf{6 1 , 6}-\mathbf{7 4 , 5}$ & $\mathbf{3 3 , 5}-\mathbf{4 0 , 3}$ \\
9 & $20,8-24,4$ & $74,6-87,9$ & $40,5-47,5$ \\
10 & $24,5-28,4$ & $88,0-102,3$ & $47,7-55,3$ \\
11 & $28,5-32,6$ & $102,4-117,0$ & $55,5-63,4$ \\
12 & $>32,6$ & $>117,0$ & $>63,4$ \\
\hline
\end{tabular}

Dari pendefinisian masing-masing kelas untuk kecepatan rata-rata angin seperti pada tabel 1 diatas, kategori angin dengan kecepatan rendah atau Low Wind Speed (LWS) berada pada klasifikasi kelas III dan kelas IV [16]. Angin kelas 3 adalah batas minimum dan angin kelas 8 adalah batas maksimum energi angin yang dapat dimanfaatkan untuk menghasilkan energi listrik.

\section{B. Turbin Angin}

Terdapat dua jenis turbin angin ditinjau dari posisi sudu atau bilah yaitu, Horizontal Axis Wind Turbine (HAWT) dan Vertical Axis Wind Turbine (VAWT) [17]. Putaran turbin dihasilkan melalui penangkapan angin oleh bagian efektif dari sudu turbin yang menghasilkan tekanan dorong dan menimbulkan efek rotasi pada turbin angin. Dilihat dari bentuknya, kubah masjid putar termasuk jenis Vertical Axis Wind Turbine tipe Darius. Adapun kesamaan prinsip kerja dari kubah putar dan turbin angin bertipe VAWT ditunjukkan pada Gambar 1 berikut :

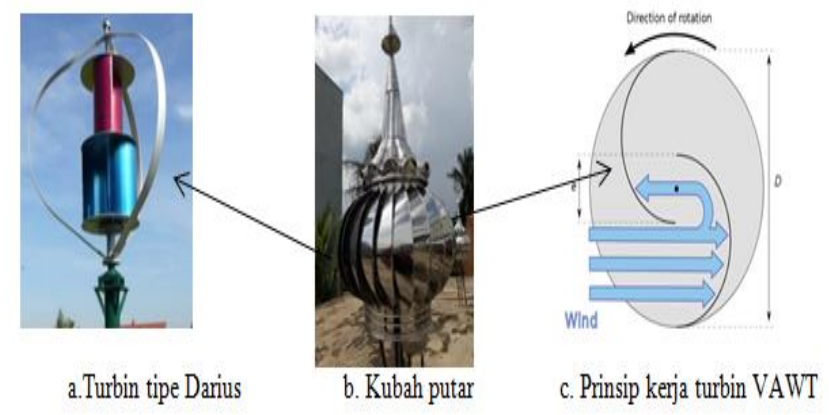

Gbr. 1 Kubah Putar dan Turbin Angin jenis VAWT tipe Darius 
C. Generator Magnet Permanen dan Generator DC

Bila suatu bahan magnetik mengalami gaya permagnetan yang kuat, maka domaindomain gaya medan magnetiknya akan tersusun pada arah yang sama dimana kutub Utara menjadi tempat masuknya gaya magnetik sementara kutub Selatan menjadi tempat keluarnya. Bila gaya permagnetannya dihilangkan, maka sebagian besar domainnya tetap berada dalam arah yang teratur. Inilah yang menjadi prinsip medan magnet permanen. Pada generator magnet permanen, magnet ditempatkan di bagian rotor yang berfungsi untuk menghasilkan medan magnet yang berputar. Medan magnet putar yang dihasilkan akan menginduksi kumparankumparan pada bagian stator, sehingga diujung-ujung belitan stator akan timbul ggl induksi. Hal ini sesuai dengan Hukum Faraday yang dirumuskan sebagai berikut :

$$
e=-N(d \varnothing) / d t
$$

dengan :

$\mathrm{N} \quad=$ jumlah kumparan

$\mathrm{d} \Phi / \mathrm{dt}=$ perubahan fluks terhadap waktu

Ggl induksi ini berlawanan arah dengan arah fluks sehingga menimbulkan arus induksi sesuai dengan Hukum Lenz.

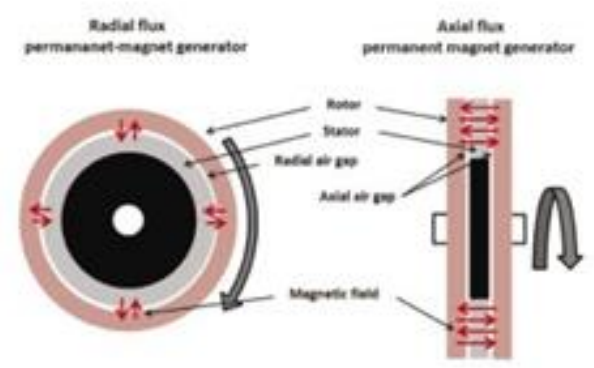

Gbr. 2 Generator magnet permanen

Generator DC juga menggunakan prinsip yang sama. Seperti ditunjukkan pada Gambar 3, dimana kumparan rotor $\mathrm{ABCD}$ terletak dalam medan magnet sedemikian rupa sehingga sisi A-B dan C-D terletak tegaklurus pada arah fluks magnet. Kumparan rotor (penghantar) $\mathrm{ABCD}$ diputar dengan kecepatan sudut yang tetap terhadap sumbu putarnya yang sejajar dengan sisi A-B dan C-D menimbulkan ggl induksi yang terbentuk pada sisi A-B dan sisi C-D.
Besarnya ggl induksi sesuai dengan perubahan fluks magnet yang dipotong kumparan $\mathrm{ABCD}$ tiap detik, sebagaimana persamaan (4) di atas.

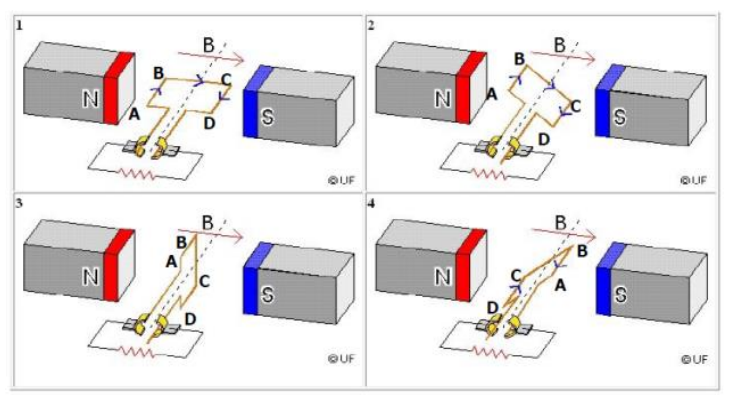

Gbr. 3 Prinsip kerja generator DC

Pada generator DC arah arus induksinya tidak berubah, disebabkan cincin yang digunakan pada generator DC berupa cincin belah (komutator). Gambar 4 menunjukkan gelombang tegangan berbentuk setengah lingkaran yang berulang secara periodik sebagai hasil dari berbagai posisi rotor generator DC. Terlihat bahwa tegangan selalu bernilai positif dikarenakan arus searah yang dihasilkan generator DC.



Gbr. 4 Grafik tegangan Generator DC

\section{METODOLOGI PENELITIAN}

Langkah pertama yang dilakukan adalah mengukur kecepatan angin di beberapa titik di dalam kota Palembang untuk menentukan lokasi pengujian generator magnet permanen. Peneliti berasumsi bahwa kecepatan angin di dalam kota relatif rendah sehingga generator magnet permanen dipilih untuk diujikan. Pengukuran dilakukan pada tempat-tempat yang relatif bebas hambatan dan lapang sehingga angin berhembus tanpa hambatan. Tempat yang memiliki kecepatan angin yang lebih baik dipilih sebagai tempat pengujian. Setelah lokasi ditentukan dilanjutkan dengan membuat generator magnet permanen menggunakan magnet Neodymium berukuran 
$50 \mathrm{~mm} \times 10 \mathrm{~mm} \times 5 \mathrm{~mm}$ yang ditempatkan pada masing-masing rotor sejumlah 8 buah magnet. Generator didesain untuk bekerja pada frekuensi $50 \mathrm{~Hz}$ dengan jumlah kutub 8 buah. Selanjutnya menentukan diameter luar dan dalam stator, dimana pada penelitian ini perbandingan diameter dalam dan luar adalah $1: \sqrt{3}$ dengan penentuan diameter luar mengikuti persamaan berikut [18].

$$
D_{\text {out }}=\sqrt[3]{\frac{\varepsilon \cdot P_{\text {out }}}{\pi^{2} \cdot k_{D} \cdot k_{w 1} \cdot n \cdot B_{m g} \cdot A_{m} \cdot \eta \cdot \operatorname{Cos} \varphi}}
$$

dengan :

Faktor daya atau $\cos \varphi=0,8$

Effisiensi $=80 \% / 100 \%=0,8 \%$

$\mathrm{P}=$ jumlah kutub

$\mathrm{n}=6,25$

$\mathrm{V} 1=220 \mathrm{~V}$

Ratio tegangan, $\varepsilon=\frac{E_{f}}{V_{1}}=2$ (desain untuk motor $\varepsilon<1$ dan generator $\varepsilon>1$ )

$B_{m g}=0,65 T$

$A_{m}=32500 \mathrm{~A} / \mathrm{m}$

$K_{w 1}=0,96$

$k_{D}=0,131$

Dari diameter stator dapat dihitung besarnya fluks yang akan dihasilkan menggunakan persamaan (6). Besarnya fluks akan menentukan jumlah lilitan pada stator berdasarkan persamaan (7).

$$
\begin{aligned}
\phi_{f} & =\alpha_{i} \cdot B_{m g} \cdot \frac{\pi}{2 p}\left[\left(0,5 \cdot D_{\text {out }}\right)^{2}\right]-\left[\left(0,5 \cdot D_{\text {in }}\right)^{2}\right] \\
N_{1} & =\frac{E}{4,44 \cdot f \cdot K_{w 1} \cdot \phi_{f}}
\end{aligned}
$$

Untuk bagian rotor menggunakan akrilik sebagai rumah untuk melekatkan magnet permanennya. Dengan luas diameter luar dan diameter dalamnya sama dengan luas diameter stator. Generator pada penelitian ini menggunakan dua buah rotor. Sedangkan bagian stator terdiri dari 8 kumparan kawat email, dengan 600 lilitan di tiap kumparan yang dihitung menurut persamaan (7) dan dikeraskan dengan cairan resin. Pada penelitian ini, generator yang dihasilkan adalah generator 1 fasa berdiameter $20 \mathrm{~cm}$ dan tebal $3 \mathrm{~cm}$.

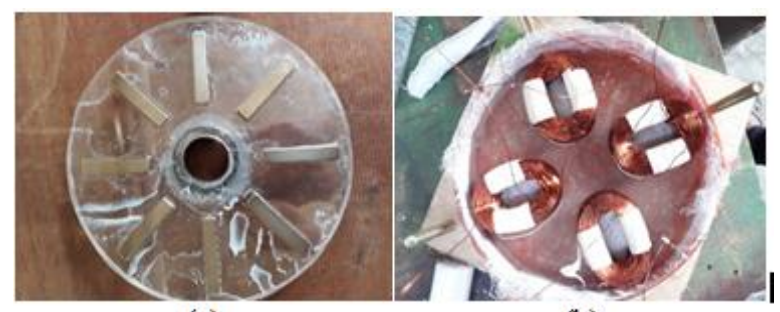

(a)

(b)

Gbr.5 Konstruksi rotor (a) dan stator (b) generator magnet permanen

Selanjutnya generator dikopelkan dengan turbin kubah masjid putar seperti ditunjukkan pada Gambar 5. Kubah yang digunakan adalah kubah yang tersedia di pasaran, berdiameter 60 $\mathrm{cm}$ dengan kemiringan sudu $30^{\circ}$ dan jumlah sudu sebanyak 24 buah.



Gbr.6 Rangkaian turbin kubah putar dan generator magnet permanen

Sedangkan lokasi pengujian untuk generator DC, dipilih kawasan perairan Sungsang Kabupaten Banyuasin yang jarak dan waktu tempuhnya relatif dekat dari Kota Palembang. Peneliti berasumsi kecepatan angin di kawasan ini lebih tinggi sehingga lebih cocok untuk menjadi lokasi pengujian generator DC yang konstruksinya lebih berat dari generator magnet permanen. Generator DC dikopelkan dengan turbin kubah putar melalui gear dengan perbandingan $1: 2$. Kubah putar yang dipakai identik dengan yang dikopelkan dengan generator magnet permanen.

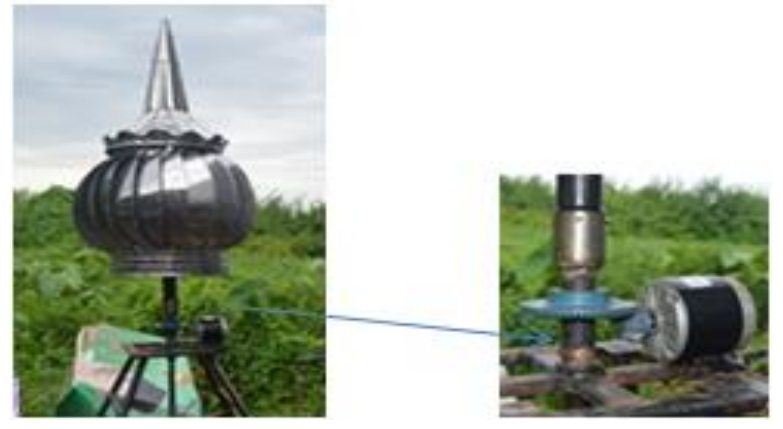

Gbr. 7 Rangkaian turbin kubah putar dan generator DC 
Generator DC yang diuji mempunyai tegangan output 24 V DC, $2750 \mathrm{rpm}$, arus nominal 19.2 A dan daya output $350 \mathrm{~W}$. Untuk mendapatkan hasil yang optimal rangkaian ditempatkan di atas perahu jukung dan pengujian dilakukan di perairan Sungsang Kabupaten Banyuasin yang merupakan muara Sungai Musi, berjarak sekitar $70 \mathrm{~km}$ dari Kota Palembang. Waktu pengujian dari pukul 13.00 hingga pukul 17.00WIB.
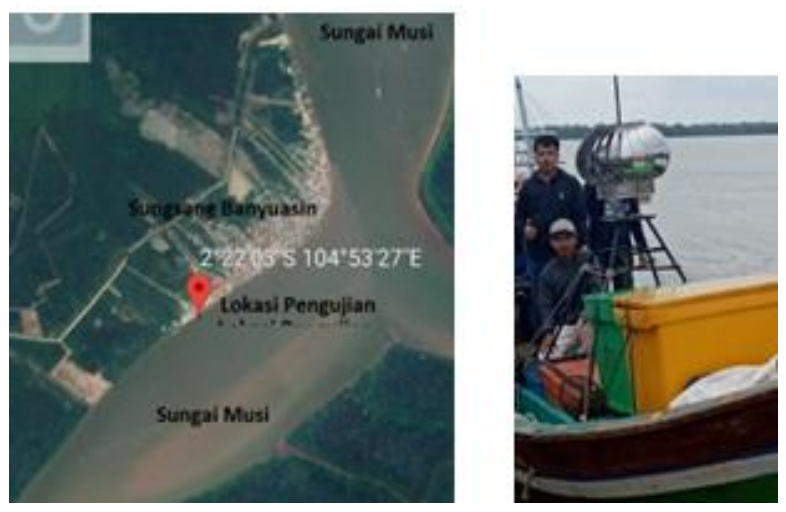

Gbr.8 Lokasi pengujian generator DC

\section{HASIL DAN PEMBAHASAN}

Pengukuran kecepatan angin di Kota Palembang dilakukan pada lima lokasi. Dari kelima lokasi, Jembatan Musi 2 memiliki kecepatan angin yang lebih baik sehingga dipilih menjadi lokasi pengujian. Hasil pengukuran tertera pada Tabel 2 berikut :

Tabel 2. Hasil Pengukuran Kecepatan Angin Kota

\begin{tabular}{lcc}
\hline \multicolumn{3}{c}{ Palembang } \\
\hline No & Lokasi & $\begin{array}{c}\text { Kecepatan Angin } \\
(\mathbf{m} / \mathbf{d e t})\end{array}$ \\
\hline 1 & Musium Purbakala & $1,4-3,2$ \\
2 & Jembatan Musi 2 & $2,7-5,0$ \\
3 & Jalan Lingkar Selatan & $0,5-2,4$ \\
4 & Jembatan Ampera & $2,4-3,9$ \\
5 & Benteng Kuto Besak & $2,4-3,7$ \\
\hline
\end{tabular}

Uji lapangan turbin kubah putar dengan generator magnet permanen dimulai pukul 14:00 WIB sampai dengan 17:00 WIB. Pengambilan data dilakukan setiap 10 menit sekali. Berikut hasil pengukuran keluaran tegangan generator magnet permanen :
Tabel 3. Besaran tegangan output generator magnet permanen - turbin kubah putar

\begin{tabular}{ccccc}
\hline No & $\begin{array}{c}\text { Pukul } \\
\text { (WIB) }\end{array}$ & $\begin{array}{c}\text { Kecepatan } \\
\text { Angin }\end{array}$ & $\begin{array}{c}\text { Tegangan } \\
\text { Output }\end{array}$ & $\begin{array}{c}\text { Arus } \\
\text { Output }\end{array}$ \\
\hline $\mathbf{1}$ & $14: 00$ & $4,1 \mathrm{~m} / \mathrm{s}$ & $11,59 \mathrm{~V}$ & $0,3 \mathrm{~A}$ \\
$\mathbf{2}$ & $14: 10$ & $3,1 \mathrm{~m} / \mathrm{s}$ & $3,12 \mathrm{~V}$ & $0,3 \mathrm{~A}$ \\
$\mathbf{3}$ & $14: 20$ & $3,2 \mathrm{~m} / \mathrm{s}$ & $5,71 \mathrm{~V}$ & $0,3 \mathrm{~A}$ \\
$\mathbf{4}$ & $14: 30$ & $3,7 \mathrm{~m} / \mathrm{s}$ & $8,22 \mathrm{~V}$ & $0,3 \mathrm{~A}$ \\
$\mathbf{5}$ & $14: 40$ & $2,3 \mathrm{~m} / \mathrm{s}$ & $1,5 \mathrm{~V}$ & $0,3 \mathrm{~A}$ \\
$\mathbf{6}$ & $14: 50$ & $3,7 \mathrm{~m} / \mathrm{s}$ & $5,3 \mathrm{~V}$ & $0,3 \mathrm{~A}$ \\
$\mathbf{7}$ & $15: 00$ & $3,8 \mathrm{~m} / \mathrm{s}$ & $14,21 \mathrm{~V}$ & $0,3 \mathrm{~A}$ \\
$\mathbf{8}$ & $15: 10$ & $2,5 \mathrm{~m} / \mathrm{s}$ & $2,35 \mathrm{~V}$ & $0,3 \mathrm{~A}$ \\
$\mathbf{9}$ & $15: 20$ & $2,9 \mathrm{~m} / \mathrm{s}$ & $5,10 \mathrm{~V}$ & $0,3 \mathrm{~A}$ \\
$\mathbf{1 0}$ & $15: 30$ & $2,7 \mathrm{~m} / \mathrm{s}$ & $2,28 \mathrm{~V}$ & $0,3 \mathrm{~A}$ \\
$\mathbf{1 1}$ & $15: 40$ & $3,5 \mathrm{~m} / \mathrm{s}$ & $6,25 \mathrm{~V}$ & $0,3 \mathrm{~A}$ \\
$\mathbf{1 2}$ & $15: 50$ & $3,7 \mathrm{~m} / \mathrm{s}$ & $3,4 \mathrm{~V}$ & $0,3 \mathrm{~A}$ \\
$\mathbf{1 3}$ & $16: 00$ & $2,8 \mathrm{~m} / \mathrm{s}$ & $3,1 \mathrm{~V}$ & $0,3 \mathrm{~A}$ \\
$\mathbf{1 4}$ & $16: 10$ & $3,9 \mathrm{~m} / \mathrm{s}$ & $6,05 \mathrm{~V}$ & $0,3 \mathrm{~A}$ \\
$\mathbf{1 5}$ & $16: 20$ & $3,4 \mathrm{~m} / \mathrm{s}$ & $5,64 \mathrm{~V}$ & $0,3 \mathrm{~A}$ \\
$\mathbf{1 6}$ & $16: 30$ & $2,7 \mathrm{~m} / \mathrm{s}$ & $4,23 \mathrm{~V}$ & $0,3 \mathrm{~A}$ \\
$\mathbf{1 7}$ & $16: 40$ & $2,8 \mathrm{~m} / \mathrm{s}$ & $3,25 \mathrm{~V}$ & $0,3 \mathrm{~A}$ \\
$\mathbf{1 8}$ & $16: 50$ & $3,1 \mathrm{~m} / \mathrm{s}$ & $3,12 \mathrm{~V}$ & $0,3 \mathrm{~A}$ \\
$\mathbf{1 9}$ & $17: 00$ & $3,4 \mathrm{~m} / \mathrm{s}$ & $7,23 \mathrm{~V}$ & $0,3 \mathrm{~A}$ \\
\hline & & & &
\end{tabular}

Kecepatan angin yang relatif menghasilkan tegangan yang cukup tinggi berada pada kisaran $3 \mathrm{~m} / \mathrm{det}$, dimana tegangan maksimum yang didapat sebesar 14,21 volt DC pada kecepatan angin 3,8 $\mathrm{m} / \mathrm{det}$. Arus yang dihasilkan konstan sebesar 0,3 A DC. Dengan demikian kubah putar masjid hendaklah ditempatkan pada lokasi yang memiliki kecepatan angin rata-rata di atas 3,5 m/det.

Hasil pengukuran menunjukkan bahwa perubahan kecepatan angin yang drastis mengakibatkan tegangan output yang berbeda pada kecepatan yang sama,seperti terlihat pada kecepatan angin 3,7 m/det yang menghasilkan tegangan $8,22 \mathrm{~V} ; 5,3 \mathrm{~V}$ dan 3,4 V. Namun bila perubahan kecepatan angin relatif lebih smooth, tegangan output meningkat secara bertahap dan relatif lebih stabil. Hasil ini menunjukkan bahwa turbin kubah putar akan memberikan hasil optimal pada kondisi kecepatan angin yang cenderung konstan. Sedangkan untuk generator DC, pengukuran dilakukan setiap 30 menit sekali. Hasil pengukuran kecepatan angin dan besarnya parameter listrik yang dihasilkan ditunjukkan pada tabel 4 berikut: 
Tabel 4. Besaran tegangan output generator DCturbin kubah putar

\begin{tabular}{ccccc}
\hline No & $\begin{array}{c}\text { Pukul } \\
\text { (WIB) }\end{array}$ & $\begin{array}{c}\text { Kecepatan } \\
\text { Angin }\end{array}$ & $\begin{array}{c}\text { Tegangan } \\
\text { Output }\end{array}$ & $\begin{array}{c}\text { Arus } \\
\text { Output }\end{array}$ \\
\hline $\mathbf{1}$ & $13: 00$ & $2 \mathrm{~m} / \mathrm{s}$ & - & - \\
$\mathbf{2}$ & $13: 30$ & $3,4 \mathrm{~m} / \mathrm{s}$ & - & - \\
$\mathbf{3}$ & $14: 00$ & $5 \mathrm{~m} / \mathrm{s}$ & $1,8 \mathrm{~V}$ & - \\
$\mathbf{4}$ & $14: 30$ & $5,6 \mathrm{~m} / \mathrm{s}$ & $1,8 \mathrm{~V}$ & - \\
$\mathbf{5}$ & $15: 00$ & $6 \mathrm{~m} / \mathrm{s}$ & $1,5 \mathrm{~V}$ & - \\
$\mathbf{6}$ & $15: 30$ & $5 \mathrm{~m} / \mathrm{s}$ & $2,19 \mathrm{~V}$ & - \\
$\mathbf{7}$ & $16: 00$ & $6,6 \mathrm{~m} / \mathrm{s}$ & $1,8 \mathrm{~V}$ & - \\
$\mathbf{8}$ & $16: 30$ & $6 \mathrm{~m} / \mathrm{s}$ & $2,5 \mathrm{~V}$ & - \\
$\mathbf{9}$ & 17.00 & $8 \mathrm{~m} / \mathrm{s}$ & $3 \mathrm{~V}$ & - \\
\hline Note $: *$ - tidak terbaca oleh alat ukur &
\end{tabular}

Hasil pengujian menunjukkan bahwa pengggunaan generator DC pada turbin kubah putar belum menghasilan besaran parameter listrik yang diharapkan. Tegangan maksimum yang dapat terbaca alat ukur hanya $3 \mathrm{~V}$, sementara besaran arus tidak terbaca,walaupun kecepatan angin relatif lebih tinggi dan stabil dibandingkan dengan kecepatan angin di Kota Palembang. Selama pengujian, turbin kubah putar dapat berputar dengan baik secara kontinu dan kecepatan putar turbin bertambah seiring pertambahan kecepatan angin. Hal ini menunjukkan susunan bilah-bilah kubah memiliki daya tangkap angin yang baik. Akan tetapi pertambahan ini belum mampu membuat putaran generator menghasilkan arus dan tegangan yang diinginkan. Beberapa kemungkinan penyebab tidak tercapainya hasil yang diinginkan diantaranya :

- Konstruksi shaft dan bearing yang masih berat secara mekanis

- Kurang akuratnya perbandingan gear yang dipakai

- Besarnya rugi-rugi transmisi mekanik

- Spesifikasi generator DC yang kurang tepat

Bila kedua pengujian dibandingkan, pengunaan generator magnet permanen menghasilkan hasil yang lebih baik. Jika dilihat dari kemampuan daya tangkap angin turbin kubah putar yang relatif baik, generator magnet permanen secara perbandingan matematis mampu menghasilkan tegangan output hingga $30 \mathrm{~V}$ pada kecepatan angin 8 $\mathrm{m} /$ det. Dengan kata lain, generator magnet permanen dapat menghasilkan arus keluaran yang memadai untuk charging batere.

\section{KESIMPULAN}

Kubah putar masjid memiliki potensi yang baik untuk dimanfaatkan sebagai turbin angin. Jenis generator yang lebih mendukung pemanfaatan kubah putar sebagai turbin angin adalah generator magnet permanen. Konstruksinya yang ringan, sederhana dan dapat dikopelkan langsung dengan turbin kubah tanpa melalui transmisi gear. Tegangan output generator magnet permanen lebih bervariasi daripada generator DC.

Penggunaan kedua generator belum menghasilkan arus output yang memadai untuk pengisian batere, terutama pada generator DC. Penambahan rangkaian penguat arus dapat menjadi solusi untuk mengatasi hal tersebut. Pada generator DC, pemilihan jenis shaft dan perbandingan gear yang tepat dapat mengurangi rugi-rugi transmisi mekanik yang dapat memperbaiki nilai tegangan outputnya.

\section{UCAPAN TERIMA KASIH}

Penulis memgucapkan terimakasih kepada Lembaga Penelitian dan Pengabdian kepada Masyarakat Universitas Muhammadiyah Palembang yang telah mendanai sebagian penelitian ini dengan No. Kontrak 325/H5/LPPM-UMP/XI/2019.

\section{REFERENSI}

[1] A. I. Ridwanullah and D. Herdiana, "Optimalisasi Pemberdayaan Masyarakat Berbasis Masjid," Ilmu Dakwah Acad. J. Homilet. Stud., vol. 12, no. 1, pp. 82-98, Jun.2018,doi: 10.15575/idajhs.v12i1.2396.

[2] S. Sholihah, "Peran masjid raya Cinere dalam meningkatkan solidaritas sosial masyarakat Cinere Limo-Depok," Jun. 2009, Accessed: Apr. 19, 2020. [Online].Available:http://repository.uinj kt.ac.id/dspace/handle/123456789/1949 2.

[3] G. Suharjanto, "Keterkaitan Tipologi dengan Fungsi dan Bentuk: Studi Kasus Bangunan Masjid," ComTech Comput. Math. Eng. Appl., vol. 4, no. 2, pp. 975982,Dec.2013,doi:10.21512/comtech.v4 i2.2539.

[4] T. Tjahjono and E. Widodo, 
"PENGGUNAAN ENERGI ANGIN

DAN ENERGI MATAHARI SEBAGAI

SUMBER ENERGI LISTRIK

DENGAN SISTEM HYBRID," Pros.

SNST Fak. Tek., vol. 1, no. 1, Jul. 2011, Accessed: Apr. 17, 2020. [Online]. Available:https://publikasiilmiah.unwah as.ac.id/index.php/PROSIDING_SNST.

[5] J. Haurissa and S. E. Santoso, "STUDI DAN ANALISA TURBIN VENTILATOR MENJADI PEMBANGKIT LISTRIK," J. Tek. MESIN, vol. 6, no. 2, pp. 76-86, Dec. 2017.

[6] M. Padmika, I. M. S. Wibawa, and N. L. P. Trisnawati, "Perancangan Pembangkit Listrik Tenaga Angin Dengan Turbin Ventilator Sebagai Penggerak Generator," Bul. Fis., vol. 18, no. 2, pp. 68-73, Sep. 2017, doi: 10.24843/BF.2017.v18.i02.p05.

[7] J. Jamaludin, "ANALISA PEMANFAATAN TURBIN VENTILATOR SEBAGAI SUMBER LISTRIK SKALA RUMAH TANGGA," Simp. Nas. Mulitidisiplin SinaMu, vol. 0, no. 0, Aug. 2019, Accessed: Apr. 17, 2020. [Online]. Available:http://jurnal.umt.ac.id/index.p $\mathrm{hp} /$ senamu/article/view/2138.

[8] A. Suryadi, P. T. Asmoro, and R. Raihan, "Pemanfaatan Turbin Ventilator sebagai Pembangkit Listrik Alternatif," Pros. Semin. Nas. Teknoka, vol. 4, p. E-15-E19, Dec. 2019, doi: 10.22236/teknoka.v4i0.4124.

[9] M. Adam, "Analisa Pengaruh Perubahan Kecepatan Angin Pada Pembangkit Listrik Tenaga Angin (PLTA) Terhadap Daya Yang Dihasilkan Generator Dc," RELE Rekayasa Elektr. Dan Energi J. Tek. Elektro, vol. 2, no. 1, pp. $30-36$, Aug. 2019, doi: 10.30596/rele.v2i1.3648.

[10]A. Dimas Priyambodo and A. Imam Agung, "Prototype Pembangkit Listrik Tenaga Angin Menggunakan Generator DC Di Pelabuhan Tanjung Perak Surabaya," J. Tek. ELEKTRO, vol. 8, no. 2, Jan. 2019, Accessed: Apr. 17, 2020. [Online].

Available: https://jurnalmahasiswa.unesa.ac.id/inde
x.php/JTE/article/view/26841.

[11]C. R. Handoko, "Pemanfaatan Low Speed Neodymium Wind Turbine Generator Sebagai Alternatif Sumber Listrik Rumah Kawasan Pesisir," in Seminar MASTER PPNS, 2018, vol. 3, no. 1, pp. 139-146.

[12]H. Asy'ari, Jatmiko, and A. Ardiyatmoko, "DESAIN GENERATOR MAGNET PERMANEN KECEPATAN RENDAH UNTUK PEMBANGKIT LISTRIK TENAGA ANGIN ATAU BAYU (PLTB)," Semin. Nas. Apl. Teknol. Inf. SNATI, vol. 0, no. 0, 2012, Accessed: Apr. 17, 2020. [Online]. Available:https://journal.uii.ac.id/Snati/a rticle/view/2963.

[13]F. Budiyanto, Mustaqim, and $\mathrm{H}$. Wibowo, "GENERATOR TURBIN ANGIN PUTARAN RENDAH," ENGINEERING, vol. 5, no. 2, 2014, Accessed: Apr. 17, 2020. [Online]. Available:http://ejournal.upstegal.ac.id/i ndex.php/eng/article/view/374.

[14]D. Y. Aji, "Desain Generator Axial Kecepatan Rendah Dengan Menggunakan Magnet Permanen," s1, Universitas Muhammadiyah Surakarta, 2013.

[15]W. A. Oktaviani, T. Barlian, H. Hilmansyah, and U. Ubaidillah, "PEMANFAATAN PUTARAN KUBAH MASJID SEBAGAI SUMBER ENERGI LISTRIK ALTERNATIF," in Prosiding Seminar Nasional AVoER-10 2018, Palembang: Fakultas Teknik Universitas Sriwijaya, 2019, pp. 512517.

[16]Z. Arifin, Heri, and H. Azis, "ANALISIS KELAYAKAN TURBIN ANGIN KECEPATAN RENDAH TIPE NT1000W DI WILAYAH TERPENCIL (Feasibility Analysis of Low Speed Wind Turbine for Isolated areas)," vol. 10, pp. 84-93, Jun. 2018, doi: 10.33322/energi.v11i1.

[17]T. N. Reksoatmodjo, "Vertical-Axis Differential Drag Windmill," J. Tek. Mesin, vol. 6, no. 2, p. 6, 2004.

[18]J. F. Gieras, R.-J. Wang, and M. J. Kamper, Axial Flux Permanent Magnet Brushless Machines. Springer Science \& Business Media, 2008. 